\title{
Study of the Impacts of Some Domestic Pollutants on the Freshwater Fish Community in the Klang River, Malaysia
}

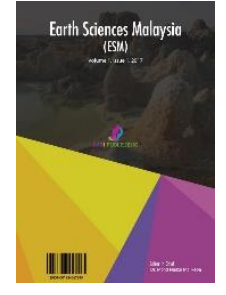

Muhammad Aqeel Ashraf ${ }^{1}$, Nur Hayati Hussin ${ }^{1}$, Ismail Yusoff' ${ }^{1}$, Mohammadreza Gharibreza ${ }^{2}$

${ }^{1}$ Department of Geology, University of Malaya, Kuala Lumpur 50603, Malaysia

${ }^{2}$ Department of Chemistry, University of Malaya, Kuala Lumpur 50603, Malaysia

${ }^{1}$ Soil Conservation and Watershed Management Research Institute, P.O. Box 13445-1136, Tehran, Iran,

This is an open access article distributed under the Creative Commons Attribution License, which permits unrestricted use, distribution, and reproduction in any medium, provided the original work is properly cited

\section{ARTICLE DETAILS}

Article history:

Received 24 October 2016 Accepted 7 December 2016 Available online 3 January 2017

Keywords:

Domestic discharge, fish community, chordate, Malaysia.

\section{ABSTRACT}

This study was carried out to determine the effects of sewage pollution on the fish assemblages found in the Klang River. Samples were collected between July 2012 and April 2013 with a total of 102 specimens belonging to 5 freshwater fish species, Puntius hexazona, Betta livida, Neohomaloptera johorensis, Parosphromenus harveyi and the dominant species, Rasbora sumatrana, with the highest dominance value (Di\%=36.66). Multiregression revealed a statistically insignificant relationship among the physical, chemical and biochemical parameters of water and sediment and Puntius hexazona, Betta livida, Neohomaloptera johorensis and Parosphromenus harveyi. Based on multiple regression tests, a significant relationship with $\mathrm{R} 2=92.2 \%$ and $\mathrm{F}=7.876(\mathrm{p}=0.000)$ was found between six water and sediment quality constituents and the numbers of Rasbora sumatrana this species at the stations studied at Site 8. On the other hand, water temperature $(\beta=-0.114 ; \mathrm{t}=-2.811(\mathrm{p}=0.016))$; sediment organic matter $(\beta=-0.011 ; \mathrm{t}=-2.406(\mathrm{p}=$

$0.033)$ ) and water phosphorus (PO4) $(\beta=0.323 ; \mathrm{t}=3.444(\mathrm{p}=0.005)$ ) were found to be the most important water and sediment parameters effecting Rasbora sumatrana.

\section{Introduction}

Water is the basic unit of life. Fresh water is a limited resource that is as important for industry and agriculture as for human existence (Khalil and Ouarda, 2009; Bartram and Ballance, 1996). There is presently an emphasis on diffuse rather than point sources of water pollution. These adverse effects on water are a result of increasing water demand from agriculture, industry, hydroelectric generation, and continued pollution. The consequences are further exacerbated by population growth, rapid urbanization and climate change (Birol et al., 2006; UNEP, 2000). From an economic perspective, water resources are over-extracted and not efficiently allocated. This is due in part to the existence of market and government failure at the local, national and international levels. Private costs and benefits diverge from social costs and benefits, leading to social welfare losses (Birol et al., 2006; Proops, 1991). The monitoring of environmental parameters is one of the highest priorities in the evaluation of the environmental status of water resources and in environmental protection policy. The main objectives are to understand and evaluate water availability and quality, to control and minimize the incidence of pollutant-oriented problems, and to provide water of appropriate quality to various water uses such as urban water supply, irrigation water, etc. (Loukas, 2010; Boyacioglu, 2006). The quality of surface water and groundwater is defined in terms of physical, chemical, and biological parameters. One problem in particular with water quality monitoring is the large number of measured variables. The datasets contain rich information regarding water resource behavior. Monitoring data classification, modeling and interpretation are the most important steps in assessing water quality (Karen, 2001).

Every human activity generates wastes in all forms, solid, gaseous, and liquid (Metcalf, 2003). Domestic water pollution from industrial, agricultural and urban areas ends up in freshwater or brackish water sources, affecting water resources if not properly treated before discharge (Botkin and Keller, 2003). Water pollution is among one of the most crucial pollution problems because communities use bodies of water for fishing, swimming and other recreational activities. It has frequently been reported that the domestic sewage disposal system in Malaysia is inadequate, and polluted rivers have sometimes caused outbreaks of waterborne diseases (Consumer's Association of Penang, 1978). Rivers play a significant role in providing water resources for human and ecosystem survival and health. Hence, river water quality is an important parameter that must be preserved and monitored. As the state of Selangor and the city of Kuala Lumpur, Malaysia, are undergoing tremendous development, the Klang River is subjected to pollution from point and non-point sources. The water quality of the Klang River basin, one of the most densely populated areas within the region, is now significantly degraded due to human activities and urbanization.

Recent reports have indicated high fecal coliform counts in the coastal water of Penang and Johor (Maheswaran, 1978). These data provide sufficient indication that our coastal water is being polluted with sewage discharge. The Klang River, which courses through Kuala Lumpur, is suspected to be heavily polluted by domestic sewage discharge. However, no studies of sewage pollution in this river have been conducted to date.

Chordates are mostly used as bioindicators and biomonitors in different aquatic ecosystems; they are known as bioindicators in polluted areas (Rinderhagen et al., 2000). Sewage pollution impacts benthic organisms. Changes due to pollution are primarily determined by the community structure of benthic fauna (Arasaki et al., 2004). Although some temporary changes in organic matter have been observed due to the initial stages of sewage pollution, sensitive species soon leave the polluted zone if pollution is a persistent problem (Bat et al., 2001). Determining the distribution of indicator species is crucial in mapping pollution gradients (Corbera and Cardell, 1995). Many studies on this topic have been carried out on polychaetes and mollusks (Belan, 1967).

Chordates are the most sensitive of benthic organisms affected by sewage pollution [Bat et al., 2001; Delval et al., 1998; Guerra-García and García-Gómez, 2004). Physical environmental factors and pollutant concentrations are important in the determination of the benthic community, and low biodiversity has been observed in sewagepollution-affected areas in coastal zones (Morrisey et al., 2003). The effects of sewage pollution on chordates in the Mediterranean ecosystem have been found in the following studies. Del Valls et al. (1998) and Guerra-García and García-Gómez (2004) studied the effects of sewage pollution on crustaceans found in the soft bottoms of two different littoral systems of Cadiz Bay (the eastern Atlantic) and of Ceuta Harbor (Gibraltar Strait). Additionally, Garcia Raso and Manjon Cabeza 
(2002) determined the effects of sewage pollution on decapod crustaceans in the upper-infralittoral zone of the Barbate Coast (the southern Spain). Recently, in Abu-Qir Bay (Alexandria, Egypt) where organic pollution occurs, Hamouda and Abdel-Salam (2010) studied the distribution models of macrobenthic communities, including cumaceans. Their findings indicated that extreme organic pollution can cause the elimination of sensitive species in an environment (Hamouda and Abdel-Salam, 2010).

On the Turkish coasts, Bat et al. (2001) described the effects of domestic wastewater discharge on several crustacean species at the depths of $0.5-1 \mathrm{~m}$ on the coast of Sinop Harbor (the southern Black Sea). Albayrak et al. (2006) sampled four different locations in the northern Marmara Sea to determine the levels of pollution due to organic material discharges. Tuğrul Içemer and Koşun (2003) carried out a study characterizing the benthic community structure subjected to sewage pollution in Antalya Bay (the eastern Mediterranean). Similar to our study, Corbera and Cardell (1995) studied indicative cumaceans affected by eutrophication in the soft bottoms of the Barcelona coast (southernSpain).

Despite several studies that have examined the effects of pollution on benthic communities of the Turkish coast (Tuğrul Içemer and Koşun (2003) for the Mediterranean Sea; Kocatas et al. (1988) for the Aegean Sea; Albayrak et al. (2006) for the Sea of Marmara; Okus et al. (1996), Yüksek et al. (2006) for the Bosporus; Bat et al. (2001) for the Black Sea), no research has indicated the effect of sewage pollutants on the structure of macrozoobenthic communities in relation to environmental conditions in the Dardanelles. The Dardanelles is a long, narrow, and shallow strait. Saros Bay, located in the northern part of the Dardanelles, is known as an important area for fisheries activity, and water from the Black Sea is discharged into the northern Aegean and the Saros after passing through the Dardanelles. Therefore, all water flowing from the Black Sea drains through this region. Thus, any type of pollution is highly expected to accumulate in theregion.

The aim of this study is to determine the effects of sewage pollution on the chordate assemblages on the soft bottoms of the Klang River, an important river in the Selangor basin.

\section{Study Area}

The Klang River (including its major tributaries of Batu, Gombak, Kerayong, and Pencala) may not be the largest in Malaysia, but the Klang Valley, which it drains, is the most developed and anthropogenically altered portion of the country. Beginning some $100 \mathrm{~km}$ from the Straits of Malacca in the Main Range of Peninsular Malaysia, it flows through the national capital of Kuala Lumpur, Petaling Jaya, Shah Alam, and Klang before reaching the sea at Port Klang. The Klang River is approximately $120 \mathrm{~km}$ long, covering a total catchment area of $1288 \mathrm{~km}$. With almost a seventh of the national population and the widest range of human activities, the physical environment in the Klang Valley has undergone many man-made changes, ranging from tin-mining during the 19th century to extensive urbanization and industrialization today. The Klang River has had to bear the full brunt of all thesechanges.

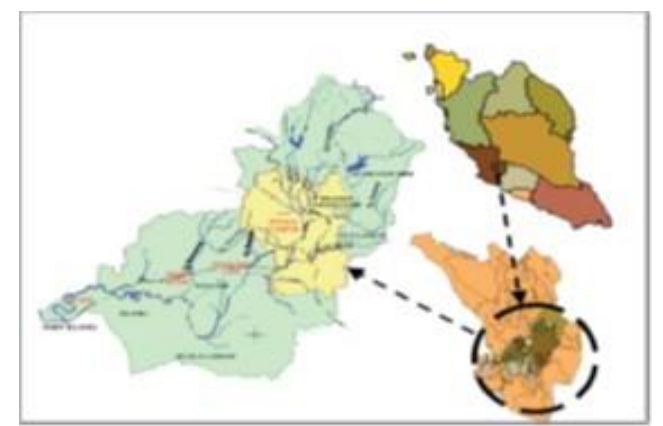

Figure 1: Klang River catchment

The Klang River faced huge threats from various sources over ten years ago due to various types of industrial activities such as the production of food and beverages, chemical manufacturing, semiconductor and electrical industries, etc. Indeed, rivers flowing through heavily populated areas are commonly associated with both point and non-point sources; consequently, it is difficult to trace the loading of pollutants in the river. Therefore, research based on advanced mathematical tools is necessary (Figure 1).

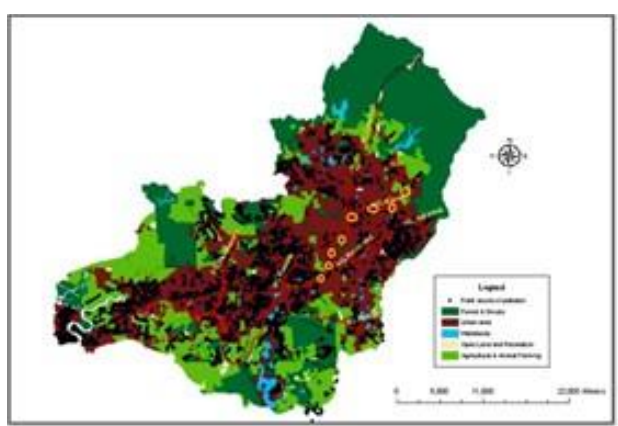

Figure 2: Klang River tributaries

\section{Klang's Environmental Stresses}

As recently as the turn of the century, the Klang River was navigable up to the point where it meets the Gombak. However, tin-mining, which contributed to the birth of Kuala Lumpur, was also one of the first major environmental stresses of the river as it discharged loads of silt into the Klang. The clearing of the jungle, first for rubber, then for buildings and roads, and finally for oil palm, increased erosion in the Klang Valley. The result has been the silting of the entire river system so that effective navigation is possible only up to the outskirts of Shah Alam. Despite the fact that tin-mining is on the decline, additional silt now comes from badly managed infrastructure.

As human population density increased in the valley and sanitation facilities failed to keep up with this growth, organic pollution of the river became serious. Although more sewage now ends in treatment plants, increased kitchen and other organic waste still moves through poorly maintained drains and ends up in the Klang River. It appears that many residents and even some officials tend to treat the river as a sewer and garbage dump. Irresponsible businesses also try to get away with dumping their waste into the river. Organic pollution has been exacerbated by the increased intrusion of chemical and industrial effluents because manufacturing and processing has increased. Although some controls and treatment have been implemented, industrial pollutants still end up in the Klang River (Figure 2).

The mandatory river reserve on both banks has been largely ignored. Development, whether legal or illegal, has occurred right up to the banks with consequent erosion and waste discharges.

Periodic dredging (to perhaps alleviate the frequent floods) has destroyed the river's fragile ecosystem, altered its course and piled ugly mounds of dredged material along the river's banks. Except for some of the upper reaches, the river is aesthetically disfigured. A documentary made by RTM in 1983 entitled 'The Fate of the Klang River' shows clearly what the river has become.

\section{Material and Methods} Sample collection, study area and field measurements

The study area is located along the Klang River, starting at the ASMA permanent water quality station at the North Port Bridge (E $101^{\circ}$ 28.339', N $03^{\circ} 02.558^{\prime}$ ) and extending to the Cannaught Bridge (E $\left.101^{\circ} 22.719^{\prime}, \mathrm{N}^{\circ} 03^{\circ} 01.173^{\prime}\right)$. The Klang River flows through Kuala Lumpur and Selangor State in Malaysia and eventually flows into the Straits of Malacca. It is approximately $120 \mathrm{~km}$ in length and drains a basin of approximately 1288 square kilometers. The study region of the Klang River and the surrounding area is shown in Figure 1. The study area includes 8 sampling points; 4 are located on the Anatolian coast and the other 4 are located on the European side. The GPS coordinates of the sampling stations are as follows:

Samples of fish species at depths of 0 to $5 \mathrm{~m}$ were collected from three different transects (depth counters of $0.5,2$ and $4 \mathrm{~m}$ ) using a quadrat system of $30 \times 30 \mathrm{~cm}$ and preserved in buffered formalin. Seasonal samplings were carried out on April 17, 2013 and July 29, 2013.

\section{Sediment types of the sampling sites}

Sampling depths were selected in localities that release domestic waste to the river. For the reference stations, the same sampling depths were adopted. Hence, the depth of each sample showed a different structure on the river bottom. The $2-5 \mathrm{~m}$ bottom of sampling station 1 is partly covered by Mytilus galloprovincialis. Sampling station 2 is silty. Eceabat station $(2-4 \mathrm{~m})$ has a sandy bottom with seagrass, Zostera marina. While sampling site 3 has fine sand, sampling site 4 is partly covered by algae and coarse sand with 
rocks. Sampling site 5 is dominated by mytilid bivalves, Mytilus galloprovincialis, at a depth of $4 \mathrm{~m}$. Sampling site 5 is covered with fine sand and the seagrass Zostera marina. Sediment organic matter was determined by $550{ }^{\circ} \mathrm{C}$ incineration of washed known weights of sediment samples (generally 50 grams) for two hours. The difference between the incinerated and raw sediment weights provided the percent organic matter. Sediment organic matter was determined by the high-temperature oxidation method adopted by Craft et al. (1991). In addition to loss of ignition at $550{ }^{\circ} \mathrm{C}$ using a furnace, organic carbon and total nitrogen were also determined by the high-temperature oxidation method. The loss of ignition method requires a weighed dry material and a furnace programmed for slowly increasing temperature to $550{ }^{\circ} \mathrm{C}$, followed by holding for 1 to 2 hours at this temperature. TOC analyzers are gaining in favor because of the short test periods required. Clean sand samples were also tested to compare with the results obtained from sediment samples.

\section{Water Quality Parameters}

Dissolved oxygen, water temperature, electrical conductivity, $\mathrm{pH}$ and salinity were measured using a YSI 556 model MPS on site. Water samples were collected in 1-liter clean, dark-colored glass bottles. Ammonia, nitrate, nitrite, biological oxygen demand, chemical oxygen demand, and anionic detergents were determined using Standard Methods (APHA, 2005). Moreover, organic constituents in the water were determined using a Hach-5000 spectrophotometer. Three replicates were tested for all parameters, and statistically no differences were found after data evaluation. Quality control was ensured when testing parameters in the laboratory.

\section{Ecological Data Analyses}

A triocular stereomicroscope was used to identify fish specimens found in the study area. Fish specimens were defined based on Ledoyer (1965). To elucidate the community structure, Soyer's (1970) frequency index ('f\%), Bellan-Santini's (1969) quantitative dominance index (Di\%), and Shannon's diversity index (1949) $\left(\mathrm{H}^{\prime}\right)$, as well as its evenness component $\left(\mathrm{J}^{\prime}\right)$ and Bray-Curtis's (1957) similarity index were calculated. The community structure was investigated by groupaveraging cluster analysis based on Bray-Curtis similarity. To calculate Shannon's diversity index $\left(\mathrm{H}^{\prime}\right)$ and its evenness component $\left(\mathrm{J}^{\prime}\right)$, primer program 6.0 was used. The frequency index of a particular species was estimated by

$f=(m / M) x 100$

Where $\mathrm{m}$ is the number of stations where the species of concern exists $\mathrm{M}$ is the total number of stations. The dominance index of a certain species was estimated by $\mathrm{Di}=(\mathrm{m} / \mathrm{M}) \times 100$, where $\mathrm{m}=$ number of individuals of a species at a station and $\mathrm{M}=$ total number of individuals of all species.

The Shannon-Weaver diversity index was estimated by $\mathrm{H}^{\prime}=-\Sigma$ pi $x$ $\left(\log _{2} p i\right)$, Where $\mathrm{S}=$ total number of individuals of a species and $\mathrm{N}=$ total number of individuals of all species. The Pielou evenness index was estimated by $J^{\prime}=H^{\prime} / \log _{2} S$ where $H^{\prime}=$ Shannon index value; $\mathrm{S}=$ species number Bray-Curtis Sjk=100 $\{1-|\Sigma| y \ddot{j}-$ yik $|/ \Sigma| y i j+y i k||\}$

\section{Statistical Data Analyses}

Variance analyses were completed to see whether there were significant differences among sampling sites and between sampling times (seasons). These analyses were completed using SPSS 10.0. Moreover, physical and chemical water quality parameters were tested to determine which ones were correlated. The Friedmann test was adopted to calculate the fish species distribution with respect to seasonal changes.

$$
\mathrm{FD}=\left[12 /(b \times \mathrm{t} \times(\mathrm{t}+1)] \times \Sigma[(\mathrm{S}))_{2}-(3 \times b \times(\mathrm{t}+1)]\right.
$$

Where $b$ is the number of sampling stations (8) and $t$ is the number of seasons (4) Sj: standard deviation of the data set.

All collected parameters were evaluated using MANOVA (multiple analysis of variance). The relationship between species composition and pollutants was evaluated using Spearman's Correlation. The relationship between the physico-chemical parameters and domestic pollutants in river water was determined by canonical discriminant analysis.

\section{Results}

\section{Environmental conditions}

The seasonal mean dissolved oxygen (DO) concentration was 7.13 $( \pm 0.59) \mathrm{mg} / \mathrm{L}$. Site 1 was found to have the highest DO concentration
( $9.79 \mathrm{mg} / \mathrm{L}$ ) in April 2013. Discharge site 2 was found to have the lowest DO value (3.68 mg/L) in July 2013. The sampling period was $7.96 \mathrm{mg} / \mathrm{L}$ at discharge sampling site 3 , while the lowest $(6.18 \mathrm{mg} / \mathrm{L})$ was found at sampling site 4 , taking into account all individual samplings. The seasonal average salinity was computed to be 25.52 $( \pm 1.30) \%$ for all sampling sites and times. Sampling discharge site 5 was found to have the highest salinity (30.5\%o) in November 2013. Discharge sampling site 1 was found to have the lowest salinity value (23.6\%o) in April 2013. The highest mean salinity observed during the sampling period was $28.87 \%$ (found at discharge sampling site 5), while the lowest $(24.55 \% 0$ ) was found at sampling discharge site 1 . The mean water temperature for all stations and sampling times was determined to be $16.02( \pm 5.82){ }^{\circ} \mathrm{C}$ for the sampling area. The highest water temperature $\left(26.77^{\circ} \mathrm{C}\right)$ was recorded at sampling site 4 in July 2013 , while the lowest $\left(8.87^{\circ} \mathrm{C}\right)$ was recorded at discharge site 3 in February 2013. The highest mean water temperature based on all sampling times was found at sampling site $3\left(16.45^{\circ} \mathrm{C}\right)$, while discharge site 2 had the lowest $\left(15.59^{\circ} \mathrm{C}\right)$.

The number of species and individuals

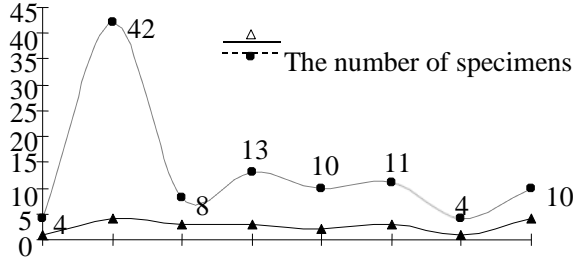

Site 1 Site 2 Site3 Site 4 Site 5 Site 6 Site 7 Site 8 $\mathrm{S}$ ampling stations

Figure 3: Number of species and individuals recorded at the sampling stations.

Table 1 includes all the physical and chemical data measured in the sampling area. Based on two-way ANOVA, only sampling time was found to create significant differences in DO, $\mathrm{pH}$ and sea water temperature. However, both sampling times and sampling sites were found to create significant differences in salinity and electrical conductivity, according to two-way analysis of variance (MANOVA). Water Pollutants (NH4+, NO3-, NO2-, PO4-3, Sediment Organic Matter and Anionic Detergents).

The average ammonia (NH4+) concentration, based on all sampling times and locations, was computed as $35.94( \pm 50.26) \mathrm{mg} / \mathrm{L}$. The highest ammonia levels were found in site 5 and site 8 discharges as 168 and $166 \mathrm{mg} / \mathrm{L}$, respectively, in July 2012. Sites 6 and 7 both had the lowest ammonia concentration of $0.06 \mathrm{mg} / \mathrm{L}$ in April 2013. Moreover, site 4 underwent the greatest change in $\mathrm{NH} 4+$ content, improving from $3.68 \mathrm{mg} / \mathrm{L}$ in July 2012 to $0.05 \mathrm{mg} / \mathrm{L}$ in February 2013.The lowest mean ammonia concentration $(1.35 \mathrm{mg} / \mathrm{L})$ was found at site 5, taking into account all individual samplings without considering times.

The number of species and individuals

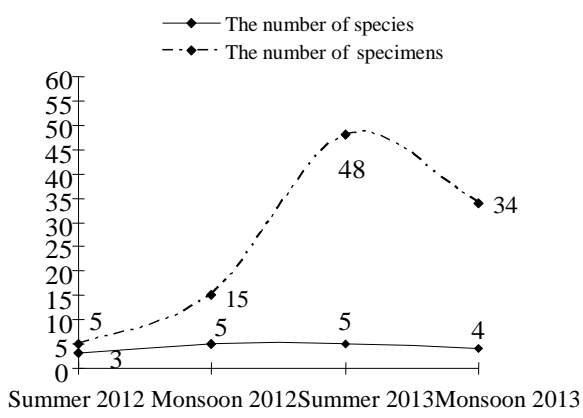

Seasons

Figure 4: Number of species and individuals found during the sampling seasons.

However, the highest ammonia concentration of all sampling stations was found in site 3 discharge at $73.73 \mathrm{mg} / \mathrm{L}$. The average nitrate (NO3-) concentration, based on all sampling times and locations, was computed as $0.30( \pm 0.22) \mathrm{mg} / \mathrm{L}$. The highest nitrate level was detected at the site 3 discharge as $0.85 \mathrm{mg} / \mathrm{L}$ in November 2012. Site 5 and Site 6 discharges were both found to have the lowest nitrate concentration of $0.01 \mathrm{mg} / \mathrm{L}$ in February 2013. The lowest mean nitrateconcentration 
$(0.14 \mathrm{mg} / \mathrm{L})$ was found at site 5 , taking into account all individual samplings but not all sampling times. However, among all sampling stations and times' resulted in the highest nitrate level of $0.54 \mathrm{mg} / \mathrm{L}$ at discharge site 3. The mean nitrite (NO2-) level for all sampling times and locations was computed as $0.057( \pm 0.04) \mathrm{mg} / \mathrm{L}$. The maximum nitrite level was measured at the site 2 discharge as $0.158 \mathrm{mg} / \mathrm{L}$ in February 2013. Interestingly, the site 4 reference station was found to have a high level of nitrite, $0.151 \mathrm{mg} / \mathrm{L}$ in February 2013. Discharge site 8 was found to have the lowest nitrite concentration of $0.004 \mathrm{mg} /$ $\mathrm{L}$ in July 2012. In terms of mean nitrite, the lowest $(0.034 \mathrm{mg} / \mathrm{L})$ was found at discharge site 7 among all individual samplings and all sampling times.

However, the highest nitrite concentration among all sampling stations without considering times was $0.089 \mathrm{mg} / \mathrm{L}$ at site 7 . The average phosphate (P04-3) concentration over all sampling times and locations was computed as $0.85( \pm 1.14) \mathrm{mg} / \mathrm{L}$. The maximum phosphate level was found at discharge site 3 as $4.78 \mathrm{mg} / \mathrm{L}$ in July 2008 , and the second-highest level was found at discharge 2 as 3.27 $\mathrm{mg} / \mathrm{L}$ in July 2012. The lowest phosphate concentration, at site 4, was $0.05 \mathrm{mg} / \mathrm{L}$ in February 2013. Considering mean phosphate, the lowest $(0.38 \mathrm{mg} / \mathrm{L})$ was detected at site 2 among all individual samplings. On the other hand, the highest phosphate levels of 1.46 and $1.44 \mathrm{mg} / \mathrm{L}$ were found at site 6 and 7 discharges, respectively (Table 2).

The mean sediment organic matter (percent SOM) of all sampling times and locations was computed as $2.85( \pm 2.16) \%$. The maximum SOM level was found at site discharge 2 as $9.86 \%$ in April 2013, possibly due to less variation in temperature, continuous sewage discharge and the structure of the site because it is less affected by flow in the strait. The lowest SOM (0.55\%) was measured at discharge 3 because the highest flow in the strait is near this site. As expected, site 3 was recorded with the lowest SOM as $1.75 \%$. The maximum mean SOM without taking into account individual sampling times (5.01\%) was detected at discharge site 8.

The mean anionic detergent value across all sampling times and locations was computed as $0.04( \pm 0.02) \mathrm{mg} / \mathrm{L}$.

Table 1. Dissolved oxygen, seawater temperature, seawater salinity, $\mathrm{pH}$, and electrical conductivity values

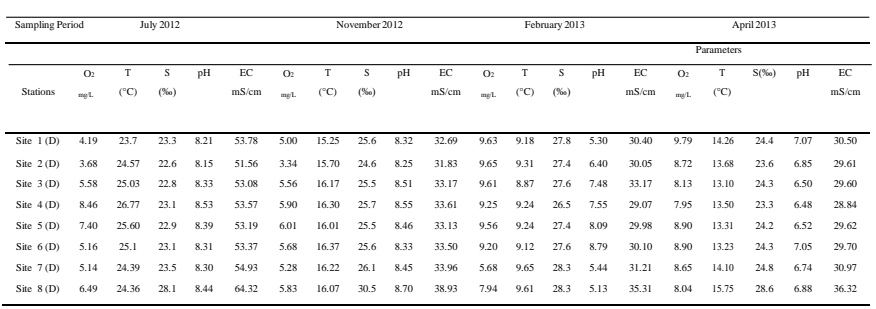

Do (mg/L): Dissolved oxygen. T $\left({ }^{\circ} \mathrm{C}\right)$ : Seawater temperature. T (\%o) Seawater salinity. pH: Activity of Hydrogen ion. EC $(\mathrm{mS} / \mathrm{cm})$ : Conductivity.

Table 2. Ammonia, nitrate, nitrite, and phosphate concentrations found during the study

\begin{tabular}{|c|c|c|c|c|c|c|c|c|c|c|c|c|c|c|c|c|}
\hline \multirow{3}{*}{ 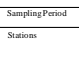 } & \multicolumn{4}{|c|}{ 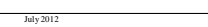 } & \multicolumn{4}{|c|}{ Novermber 2012} & \multicolumn{4}{|c|}{ Feterany 20113} & \multicolumn{4}{|c|}{ 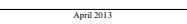 } \\
\hline & NHA & Noi & NO: & POr & NHA & No: & $\mathrm{NO}_{2}$ & Pat & NHA & Nor & NOF & $\mathrm{POH}$ & NHh & & $\mathrm{NO}=$ & $\mathrm{PO}$ \\
\hline & $(\operatorname{mog} 2 h$, & (mangly) & $(\operatorname{mes} 2)$ & $(\operatorname{men} L)$ & 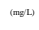 & (img & (megl) & $\ln y$ & $(\operatorname{mg} 2 L)$ & $(\operatorname{mg} L, 1)$ & (mags $L)$ & (menL) & $(\operatorname{man} 2)$ & $(\operatorname{mos} 2)$ & $(\operatorname{mos} 2)$ & $(\operatorname{man} L)$ \\
\hline (1D) & 168 & 0.08 & 0.012 & 1.34 & 56.1 & 0.76 & 0.079 & 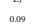 & 48.3 & 0.011 & 0.05 & 0.06 & 0.72 & 0.16 & ools & 0.10 \\
\hline (D) & 166 & 0.4 & 0.031 & 327 & 121 & 0.85 & 0.092 & 1.14 & 7.8 & 0.74 & 0.057 & 1.18 & 0.13 & 0.15 & 0.14 & 0.15 \\
\hline (D) & 1.47 & ${ }_{0.32}$ & 0.113 & 4.78 & 1.89 & 0.60 & 0.041 & 0.34 & 162 & 0.15 & 0.158 & 0.56 & 0,41 & 0.22 & 0.036 & 0.14 \\
\hline (D) & 724 & 028 & 0.039 & 1.55 & 11.6 & 0.34 & 0.028 & o.ss & 0.05 & 0.4 & 0.074 & 0.05 & 0.06 & 0.18 & 0.034 & 0.13 \\
\hline & 33 & 0.11 & 0.036 & 2.69 & 52 & 0.12 & 0.047 & 026 & 77.1 & out & 0.092 & 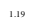 & 3.90 & 0.31 & ons & 0.10 \\
\hline & 33.7 & 0.02 & 0.031 & . & 135 & & 0.038 & 0.38 & ${ }_{35}^{35}$ & 0.17 & & 291 & 1.93 & ${ }_{0.41}$ & $\mathrm{M} 3$ & 0.35 \\
\hline , & 14 & 0.28 & 0.074 & 1.13 & 129 & 0.11 & 0.0966 & 0.12 & to & 020 & 11 & & 0.06 & 0.60 & 136 & 0.17 \\
\hline 8 (D) & 131 & 0.32 & D.004 & 126 & 973 & 0.41 & 0.034 & 0.99 & 2.71 & 0.40 & 0.118 & 0.13 & 0.40 & 020 & 0.037 & 0.99 \\
\hline & 7.4 & 0.3 & pous & 2.17 & 458 & 0.42 & 0.057 & 0.312 & 1964 & 026 & 0.10 & 0.77 & 491 & ${ }_{028}$ & 0.033 & 0.15 \\
\hline U. & (6853) & (0.14) & $(0,0.35)$ & $(0.31)$ & (142) & 1029 & (100003) & 1035 & (23.61) & (1025) & $(0.05)$ & (1999) & $(1.33)$ & (10.16) & (10011) & $(1008)$ \\
\hline
\end{tabular}

Table 3. Sediment organic matter and anionic detergent content measured during the study

\begin{tabular}{|c|c|c|c|c|c|c|c|c|}
\hline Sampling Period & July 2012 & $\begin{array}{l}\text { November } 20122 \\
\end{array}$ & February 2013 & April 2013 & & & & \\
\hline \multicolumn{9}{|l|}{$\begin{array}{l}\text { Paranceters } \\
\end{array}$} \\
\hline struiman & \%om & $\mathrm{AD}(\mathrm{m} g \mathrm{~L})$ & \%OM & $\mathrm{AD}(\mathrm{mg} / \mathrm{L})$ & $\% 0 \mathrm{M}$ & $\mathrm{AD}(\mathrm{mg} \mathrm{L})$ & $\%$ & $\mathrm{AD}(\mathrm{mg} / \mathrm{L})$ \\
\hline Site 1 (D) & 8.22 & 0.058 & 16.7 & 0.078 & 22.5 & 0.056 & 50.2 & 0.048 \\
\hline Site 2 (D) & 14.1 & 0.067 & 13.7 & 0.053 & 22.5 & 0.083 & 98.6 & 0.045 \\
\hline Site 3 (D) & 8.75 & 0.105 & 349 & 0.057 & 13.1 & 0.049 & 45.0 & 0.039 \\
\hline Site 4 (D) & 11.4 & 0.028 & 12.9 & 0.021 & 15.1 & 0.014 & 56.9 & 0.014 \\
\hline Site 5 (D) & 12.3 & 0.066 & 28.5 & 0.037 & 11.0 & 0.061 & 44.3 & 0.041 \\
\hline Site 6 (D) & 5.50 & 0.019 & 18.9 & 0.029 & 18.8 & 0.044 & 26.6 & 0.033 \\
\hline $\begin{array}{l}\text { 被 } \\
\text { Sitit } 8 \text { (D) }\end{array}$ & ${ }_{76.2}^{16.2}$ & $\begin{array}{l}0.024 \\
0.027\end{array}$ & $\begin{array}{l}19.4 \\
2.8 .6 \\
\end{array}$ & $\begin{array}{l}0.027 \\
0.026\end{array}$ & $\begin{array}{l}20.1 \\
33.2\end{array}$ & $\begin{array}{l}0.013 \\
0.018\end{array}$ & $\begin{array}{l}{ }^{46.3} \\
65.8\end{array}$ & $\begin{array}{l}0.011 \\
0.014\end{array}$ \\
\hline Average & $\begin{array}{c}12.9 \\
18.7(22.2)\end{array}$ & 0.052 & $\begin{array}{l}28.6 \\
21.7\end{array}$ & $\begin{array}{c}0.026 \\
0.041(0.02)\end{array}$ & $19.5(6.96)$ & $0.04(0.03)$ & $54.2(21.2)$ & 0.031 (0.015) \\
\hline
\end{tabular}

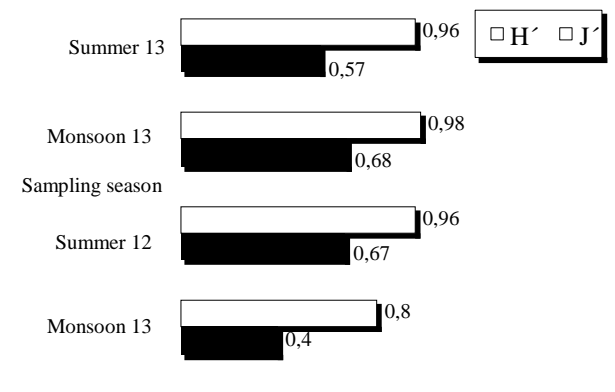

$\mathrm{H}$ and $\mathrm{J}$ values

Figure 6: Diversity $\left(\mathrm{H}^{\prime}\right)$ and evenness $\left(\mathrm{J}^{\prime}\right)$ in the seasons

The highest detergent value, $0.105 \mathrm{mg} / \mathrm{L}$, was measured at discharge site 5 in July 2012. The lowest amount of detergent, $0.011 \mathrm{mg} / \mathrm{L}$, was found at site 2 , most likely due to the nearby wastewater treatment plant, the only one in the study area, which treats domestic wastewater from houses within the Klang municipality, and to the strong sea surface current from the Klang Valley at this site.

Table 4. Total number of specimens, dominance (Di\%), and seasonal abundance (f\%) of chordates

\begin{tabular}{|c|c|c|c|}
\hline Species & 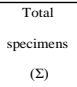 & $\begin{array}{c}\text { Dominance } \\
(\mathrm{Di} \%)\end{array}$ & Seasonal frequency $(\mathrm{f} \%)$ \\
\hline \multicolumn{4}{|l|}{ Chordate } \\
\hline Puntius hexazona & 13 & 12.74 & 100 \\
\hline Betta livida & 16 & 15.68 & 75 \\
\hline $\begin{array}{l}\text { Neohomaloptera johorensis } \\
\text { Parosphromenus havveyi }\end{array}$ & 36 & 35.29 & 100 \\
\hline Rasbora sumatrana & & $\cdots-$ & \\
\hline & 33 & 32.35 & 100 \\
\hline
\end{tabular}

Table 5. Number of specimens recorded at the sampling stations during the study.

\begin{tabular}{lcccccccc}
\hline & & \multicolumn{7}{c}{ Sampling points } \\
Species & Site 1 & Site 2 & Site 3 & Site 4 & Site 5 & Site 6 & Site 7 & Site 8 \\
& & & & & & & & \\
Puntius hexazona & 0 & 0 & 0 & 1 & 5 & 4 & 0 & 3 \\
Betta livida & 2 & 0 & 0 & 0 & 10 & 0 & 0 & 4 \\
Neohomaloptera johorensis & 6 & 9 & 1 & 2 & 13 & 0 & 4 & 1 \\
Parosphromenus harveyi & 3 & 0 & 1 & 0 & 0 & 0 & 0 & 0 \\
Rasbora sumatrana & 0 & 1 & 11 & 5 & 14 & 0 & 0 & 2 \\
\hline
\end{tabular}


All fish species found here appeared to constitute permanent components of the fauna (with f\% values $>50$ ). In July 2013, the highest number of individuals was observed $(\mathrm{n}=48)$, while Betta livida and Rasbora sumatrana were observed to have a maximum number of individuals $(\mathrm{N}=17)$ in this period.

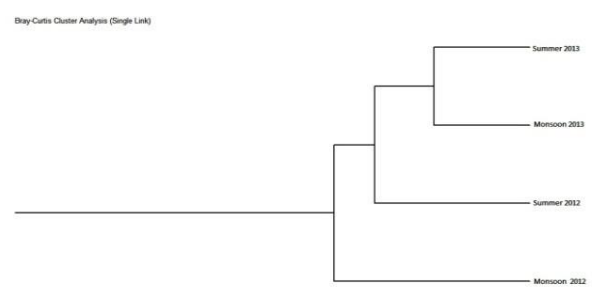

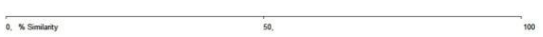

Figure 7: Similarity of the chordates community in the sampling seasons (Bray-Curtis index).

The highest number of specimens was found at the site 3 discharge station ( 42 specimens), and the lowest value was 4 at discharge sites 6 and 7 (Fig. 2, Table 5). In the study area, the maximum number of species (5) was recorded in the 2012 and 2013 monsoon seasons. The fewest species were observed in July 2012 with 3 species. The highest number of individuals (58 specimens) was recorded in November 2013. This season was followed by July 2012 with 34 specimens and February 2012 with 15 specimens. The lowest value (5 specimens) was reported in April 2012 (Fig. 3).

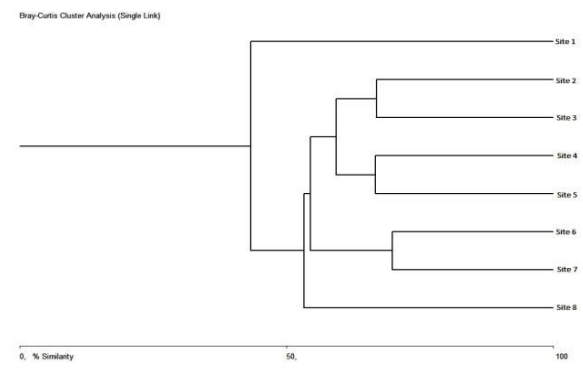

Figure 8: Similarity of the chordates community at the sampling stations (Bray-Curtis index).

The diversity index values $\left(\mathrm{H}^{\prime}\right)$ at the sampling stations ranged between 0.46 and 1.91. The evenness index $\left(J^{\prime}\right)$ values at the stations mainly ranged between 0.46 and 0.95 (Fig. 4). $\mathrm{H}^{\prime}$ values for site 2 and site 3 could not be calculated because only single species were recorded.

The seasonal values of the equitability and diversity indices showed a similar trend, and the diversity $\left(\mathrm{H}^{\prime}\right)$ was highest in February 2013. The diversity index values $\left(\mathrm{H}^{\prime}\right)$ in the sampling seasons ranged between 0.4 and 0.68 . Moreover, the evenness index $\left(\mathrm{J}^{\prime}\right)$ values according to the seasons mainly ranged between 0.80 and 0.98 (Fig. 5).

These results show that chordates were generally more abundant in the monsoon season compared to other seasons. According to the results of the Bray-Curtis similarity index, the monsoon seasons of 2013 shared the same similarity groups with a value of $81.26 \%$. The similarity value was 69.63\% between monsoon 2012 and 2013 (Fig. 6).

Bray-Curtis similarity analysis shows that discharge sites 6, 7 and 8 and reference station 4 shared the same group, and the similarity value for these stations is approximately $66 \%$. The highest similarity was observed between discharge station 3 and reference station 7 with a value of 69.74\% (Fig. 7).

The calculation of Spearman's rank correlation coefficient (rs) between biotic (species number) data and domestic pollutant parameters ( $\mathrm{NH} 4$, NO3, NO2, PO4, sediment organic matter, and anionic detergent) revealed a statistically non-significant correlation $(\mathrm{p}<0.05)$. A positive correlation was observed between the fauna (chordates) and the pollutants NO3 (rs = 0.72; $<<0.05$ ), organic matter ( $\mathrm{rs}=0.43 ; \mathrm{p}<0.05$ ), PO4 ( $\mathrm{rs}=0.42 ; \mathrm{p}<$ $0.05)$, NH4 ( $r s=0.31 ; p<0.05$ ) and anionic detergent ( $r s=0.23 ; p<0.05)$.

Puntius hexazona was found not to be statistically different at stations based on Friedman's test $(\mathrm{FD}=7.56<\chi 2(0.05 ; 7)=14.1)$. Betta livida was also not different in terms of the numbers identified by sampling stations according to the Friedman's test result $(\mathrm{FD}=4,67<\chi 2(0.05 ; 7)=$ 14.1). Neohomaloptera johorensis was determined not to be different in terms of numbers grouped by sampling stations after completing Friedman's test $(\mathrm{FD}=8,33>\chi 2(0.05 ; 7)=14.1)$. Parosphromenus harveyi also showed no significant difference among sampling stations based on the Friedman's test result $(F D=2,33<\chi 2(0.05 ; 7)=14.1)$. Rasbora sumatrana was also found not to be statistically different based on numbers according to the Friedman test $(F D=6,69<\chi 2(0.05 ; 7)=$ 14.1). In summary, the Friedman test results indicate that the stations and seasons have no effect on the number of specimens belonging to the species indicated above.

Multivariate non-parametric tests also confirmed that no statistically significant results exist. Puntius hexazona, Betta livida, Neohomaloptera johorensis, Parosphromenus harveyi and Rasbora sumatrana were found to have no statistical relationship with the water and sediment quality parameters examined (BOD5 and organic constituents of water) based upon multiple linear regression. In addition to seawater temperature $(\beta=-0.114 ; \mathrm{t}=-2.811(\mathrm{p}=0.016))$, the quantity of organic matter in the sediment $(\beta=-0.011 ; \mathrm{t}=-2.406(\mathrm{p}=0.033))$ and seawater phosphorus content (PO4) $(\beta=0.323 ; t=3.444(p=0.005))$ were found to be the most important water and sediment parameters that affect the number of individuals belong to Puntius hexazona. In addition, water temperature and sediment organic matter were determined to have a negative impact on number of individuals belonging to Puntius hexazona.

Although not found to be statistically significant, at least one parameter examined (electrical conductivity (EC), BOD5, COD, pH, OM, AD, temperature, salinity, chlorophyll-a,organic constituents in water (spectrophotometrically measured at 254 nanometers), colloidal matter, P04-3, sand percentage, sediment water content (\%), NO3-, NH4+) was found to be related with Rasbora sumatrana.

\section{Discussion}

Benthic assemblages are widely used as indicators and for the detection of human impacts on aquatic environments (Del Pilar Ruso et al., 2007). In this study, the consequences of domestic sewage discharge from different localities of the Klang River, which connects the Selangor river basin to the Straits of Malacca, and reference sites, which have natural backsides and have less pollution, were examined. The effects of raw sewage discharged at different riverside communities on macrobenthic communities were not specifically studied. With this detailed study, the effect of sewage released from communities was examined. The effects of the domestic wastewater pollution of river water (0-5 m depth) on fish species were studied. Shallow waters are known as dynamic zones because of the strong waves and the mixing of freshwater and polluted water. This natural variation may be the main reason of organism stress. However, nutrients, organic matter and influent pollutants in such environments might change the environmental circumstances (Venturini et al., 2004).

Present literature about sewage pollution in the seas indicates that environmental factors (water mass, benthic and pelagic communities, sediment, and trophic chain) are affected differently by diverse discharges (Echavarri-Erasun et al., 2007). Sewage pollution can change the structural integrity of biodiversity (Terlizzi et al., 2002). Several benthic groups such as macroalgae, tunicates, poriferans, bivalves, and crustaceans are impacted where domestic pollution is a reality. Moreover, the present populations of these organisms are declining with respect to time (Chapman et al., 1995) because domestic wastes bring nitrogen, organic carbon, and phosphorus into aquatic systems. In other words, sewage pollution is a mixture of many types of toxic matter, and it harmfully affects the biota. Eutrophication plays an important role in the destruction of biodiversity in aquatic environments (Elmanama et al., 2006).

In the presence of pollution, the dominant fish species between 5 and 13 $\mathrm{m}$ are reported to be Puntius hexazona and Betta livida, Neohomaloptera johorensis and Parosphromenus harveyi and Rasbora sumatrana below $20 \mathrm{~m}$ by Corbera and Cardell (1995). In addition, sediment organic matter was found to be between 0.6 and $1.1 \%$ in Barcelona, Spain (Corbera and Cardell, 1995). Corbera and Cardell (1995) also reported that Rasbora sumatrana has the highest biomass value and its presence is triggered with the increase of pollution. In our study, the observed chordates were Neohomaloptera johorensis, Parosphromenus harveyi and Rasbora sumatrana. These species were found in the monsoon season when the sediment organic matter was $1.95 \pm 0.69 \%$. Moreover, these species were found to be dominant at depths between 0 and $2 \mathrm{~m}$. The most dominant species were found to be Puntius hexazona (Di=35.29\%) and Betta livida (Di=32.35\%). 
Physical environmental factors and the concentrations of pollutants in seawater are important in determining the benthic community structure, and in polluted areas, the community has low species diversity (Morrisey et al., 2003). This status was the same for site 4, 5 and 6 discharges. While no species was recorded for site 7 discharge in the summer sampling, the same station had 21 chordate specimens in the spring season. The number of species for discharge point sites 2 and 3 were both 0 in the summer and were 3 and 5 , respectively, in the spring This seasonal increase in the number of specimens can be explained by excess precipitation during the spring: the additional freshwater input to the stream led to the dilution of local contaminants at site 6.

The deep discharge of domestic sewage at site 8 , caused no direct stream impacts to the horizontal surface layer, and the associated pollutants can be transported away from the discharge point. Denitrification occurs via nitrite and nitrate in water, and nitrous oxides are converted (Sawyer et al., 2003). Site 4 discharges more NH4 + and NO3- throughout the year than other stations, and its high content of accumulated sediments affects the presence of organic debris in the long term. Nitrate, one of the most important forms of nitrogen or phosphorus to biological life forms, is a characteristic of site 8 throughout the year. The organic matter content of the water in the river most likely varies with the convection dynamics. The northeast wind is generally strong, and the strong southward currents in the region have led to the removal of pollutants from the study area. Based on our observations, discharges are especially intense at night in the monsoon period in parts of the residential area of the strait. The impact of these discharges under the influence of wind and river currents may dissipate in the morning, but during the discharge period, the sunlight is less intense.

Canonical Discriminant Analysis showed that anionic detergent concentration and phosphorus concentration are the main factors among all physical and chemical factors examined in the study. Wilks' Lambda was found to be $4.981(\mathrm{p}=0.018)$ for anionic detergent and $4.977(\mathrm{p}=0.002)$ for phosphorus. Discriminant function analysis showed that physical and chemical constituents measured in this study differ notably in monsoon compared to other seasons. It is hard to tell, however, whether temperature, fresh water inputs to the system or both together cause differences among the parameters examined. It could be concluded that some physical and chemical constituents differ due to summer resorts, seasonal runoff differences, and most importantly temperature in the study area. With the expected population change, increases in some physical and chemical water quality parameters will most likely be experienced in the future if pollution control measures are not taken beforehand.

However, fewer species were recorded than expected, due to the effect of sediment, strong currents and wind on aquatic pollutants.

\section{Conclusion}

The findings from this study indicate that the Klang River water quality has been improving since 1998 in the middle and upstream stretches and has been improving since 2002-2003 in the downstream stretches. The tributaries started to show a positive trend in 2001-2003. Water quality enhancement is highly dependent on improved wastewater and sewage treatments, other improvement efforts and policies under government initiatives, and people's awareness of the need to preserve our vital water resources. Numerous campaigns and awareness programs have been promoted by the government since the 1990s to recover river water quality. The 'Love Our River Campaign' was launched in 1992 to improve the waterfront and river. This is considered to be the most comprehensive long-term awareness program on water resources in Malaysia. The campaign aimed to promote public awareness of the importance of rivers and highlight the critical state of river pollution. In addition, six main programs were carried out during this program, namely River Adoption, River Watch, River Expeditions, Education (talks, visits, briefings, etc.), River Beautification and Love Our Rivers Month. The 7th Malaysia Plan (19962000) not only focused upon ensuring more sustainable development through environment preservation but also emphasized the integration of environmental considerations with the economic and social development process. Education on environmental awareness and campaigns was also intensified to ensure active participation from all sections of society.

\section{Acknowledgements}

We would like to express our thanks to the Department of Irrigation and Drainage and the Department of Environment, Malaysia for their cooperation in performing this study. We would also like to express our gratitude to the University of Malaya through research grant BK006-2013, RG257-13AFR, FP038-2013B for supporting this study. We are most grateful and would like to thank the reviewers for their valuable suggestions, which led to a substantial improvement of the article.

\section{References}

[1] Albayrak, S., Balkıs, H., Zenetos, A., Kurun, A. and Kubanç, C. 2006. Ecological quality status of coastal benthic ecosystems in the Sea of Marmara. Mar. Poll. Bul., 52, 790-799.

[2]

APHA, AWWA WEF., 2005. 21st Edition of Standard Methods for the Examination of Water and Wastewater (Editors: Eaton, A D, Clesceri, L S, Rice, E W, Greenberg, A E). American Public Health Association, Washington, D.C.: USA.

[3] Arasaki, E., Muniz, P. and Pires-Vanin, A.M.S., 2004. A Functional Analysis of the Benthic Macrofauna of the São Sebastião Channel (Southeastern Brazil). Mar. Ecol., 25 (4), 249-263.

[4] Bartram, J and Ballance, R. (1996) Water Quality Monitoring: A Practical Guide to the Design and Implementation of Freshwater Quality Studies and Monitoring Programmes, Published on behalf of UNESCO, WHO and UNEP by E\&FN Spon,.

[5] Bat L., Akbulut, M., Sezgin, M. and Culha, M., 2001. Effects of Sewage Pollution on the Structure of the Community of Ulva lactuca, Enteremorpha linza and Rocky Macrofauna in Dıșliman of Sinop. Tr. J. Biol., 25,93-102.

[6]

Belan, G., 1967. Pollution et peuplements benthiques sur substrat meuble dans la région de Marseille. Première partie: Le secteur de Cortiou. Rev. Inter. Océanogr. Méd., 6-7, 53-87.

[7] Bellan-Santini, D., 1969. Etudefloristuque et faunistuque de quelquespeuplements infralittoraux de substrat rocheus. Rec. Trav. Sta. Mar. End., 26 (41), 237-298.

[8] Birol, E., Karousakis K., and Koundouri, P., (2006) Using economic valuation techniques to inform water resources management: A survey and critical appraisal of available techniques and an application Sci. Total Environ., 365, 105-122.

[9] Botkin, D.B. and Keller, E.A., 2003. Environmental Science: Earth as a Living Planet (4th Edition). John Wiley and Sons, Inc. Hoboken, NJ: USA, 407P.

[10] Boyacioglu, H.(2006), Surface water quality assessment using factor analysis Water SA, 32(3), 389-393.

[11] Bray, J.R. and Curtis, J.T., 1957. An ordination of the upland forest communities of South Wisconsin. Ecol. Monog., 27, 325-347.

[12] Chapman, M.G., Underwood, A.J. and Skilleter, G.A., 1995. Variability at different spatial scales between a subtidal assemblage exposed to the discharge of sewage and two control assemblages. J. Exp. Mar. Biol. Ecol., 189 (1-2), 103-122.

[13] CONSUMER'S ASSOCIATION OF PENANG (1978): The Malaysian environment in crisis selections from press cuttings. Consumer's Association Penang, 21-C, Codrington Avenue, Penang, Malaysia.

[14] Corbera, J. and Cardell, M.J., 1995. Cumaceans as indicators of eutrophication on soft bottoms. Sci. Mar., 59 (1), 63-69.

[15] Craft, C.B., Seneca, E.D., Broome, S.W. 1991. Loss on ignition and Kjeldahl digestion for estimating organic carbon and total nitrogen in estuarine marsh soils: calibration with dry combustion, Estuaries 14, 175-179.

[16] Del Pilar Ruso, Y., De la Ossa Carretero, J.A., Giménez Casalduero, F. and Sánchez Lizaso, J.L., 2007. Spatial and temporal changes in infaunal communities inhabiting soft-bottoms affected by brine discharge. Mar. Envi. Res., 64, 492-503.

[17] Del Vals, T.A., Conradi, M., Garcia-Adiego, E., Forja, J.M. and Gómez-Parra, A., 1998. Analysis of macrobenthic community structure in relation to different environmental sources of contamination in two littoral ecosystems from the Gulf of Cádiz (SWSpain). Hydrobiologia, $385,59-70$ 
[18] Echavarri-Erasun, B., Juanes, J.A., García-Castrillo, G. and Revilla, J.A., 2007. Medium-term responses of rocky bottoms to sewage discharges from a deepwater outfall in the NE Atlantic. Mar. Poll. Bul., $54,941-954$.

[19] Elmanama, A.A., Afifi, S. and Bahr, S., 2006. Seasonal and spatial variation in the monitoring parameters of Gaza Beach during 2002-2003. Envi. Res., 101, 25-33.

[20] García-Raso, J.E. and Manjón-Cabeza, M.E., 2002. An infralittoral decapod crustacean community of southern Spain affected by anthropogenic disturbances. J. Crus. Biol., 22, 83-90.

[21] Guerra-García, J.M and García-Gómez, J.C., 2004. Crustacean[38] assemblages and sediment pollution in an exceptional case study: A harbour with two opposing entrances. Crustaceana, 77 (3), 353-370.

[22] Hamouda, A.Z. and Abdel-Salam, K.M., 2010. Acoustic seabed classification of marine habitats: Studies in the Abu-Qir Bay. J. Ocean. Mar. Sci., 1 (1), 11-22.

[23] Karen, S., (2001) CCME Water Quality Index 1.0 User's Manual, 2001

Khalil, B and Ouarda, T. B.M.J. (2009) Statistical approaches used to assess and redesign surface water-quality-monitoring networks J. Environ. Monit., 11, 1915-1929.

[24] Kocataş, A., Ergen, Z., Katağan, T. and O nen, M., 1988. Evolution a long terme (1974-1987) des peuplements benthiques sur substrat meuble du Golfe d' Izmir scumis a des multiples pollutions. Rapp. Comm. Int. Mer. Medit., 31, 2.

[25] Ledoyer, M., 1965. Sur Quelques Especes Nouvelles D'Iphinoe (Crustacea Cumacea) Discussion et Description Comparative des Especes Europeennes Deja Connues. Rec. Trav. Sta. Mar. End., 39 (55), 253-295.

[26] Loukas, A. (2010) Surface water quantity and quality assessment in Pinios River, Thessaly, Greece Desalination, 2010, 250, 266-273.

[27] MAHESWARAN, A. (1978): Marine pollution and its control Paper presented at the First Marine Science Conference 'Our Seas in Perspective' convened by the Malaysian Association of Marine Science, 5 and 6 August, 1978. Universiti Pertanian Malaysia, Serdang.

[28] Metcalf and Eddy, 2003. Wastewater Engineering: Treatment and Reuse (revised by G. Tchobanoglous, F.L. Burton ve H.D. Stensel), McGraw-Hill, Inc: Boston, 1758P.

[29] Morrisey, D.J., Turner, S.J., Mills, G.N., Williamson, R.B. and Wise, B.E., 2003. Factors affecting the distribution of benthic macrofauna in estuaries contaminated by urban runoff. Mar. Envi. Res., $55,113-136$

[30] Okuș, E., Uysal, A., Yüksek, A., Altıok, H. and Tas, S., 1996. Biological aspects of the rehabilitation of Golden Horn. Submitted to: I Istanbul Water and Sewage Administration, Istanbul University, Institute of Marine Sciences and Management, 1996, Vefa, Istanbul [in Turkish].

[31] Proops, J.L.R., (1991) Ecological Economics, Economics of natural resources and the environment.: David W. Pearce and R. Kerry Turner. Harvester Wheatsheaf, Hemel Hempstead, Hertfordshire, UK, 1990. 378 pp. ISBN 0-7450-0202-1/0-7450-0225-0 vol. 3, pp. 263-265.

[32] Rinderhagen, M., Ritterhoff, J. and Zauke, G.P., 2000 Crustaceans as bioindicators. In: Gerhardt. A. (Eds.). Biomonitoring of Polluted Water -Reviews on Actual Topics. Trans Tech Publications Scitech Publications. Environmental Research Forum 2000, 9, UetikonZuerich, 161-194.

[33] Sawyer, C.N., McCarty, P.L. and Parkin, G.F., 2003. Chemistry for Environmental Engineering and Science. (5th edition), McGrawHill, Inc: Boston, 123 P.

[34] Shannon, C.E. and Weaver, V., 1949. A mathematical theory of communication, Univ. Press: 101-117, Illinois, Urbana.
[35] Soyer, J., 1970. Contribution a l'etude des copepodes harpactioides de Mediterranee occidentale, 2. Tachidiidae Sars, Lang. Vie Milieu, 21 (2-A), 261-278.

[36] Terlizzi, A., Fraschetti, S., Guidetti, P. and Boero, F., 2002. The effects of sewage discharge on shallow hard substrate sessile assemblages. Mar. Poll. Bul., 4, 544-550.

[37] Tuğrul Içemer, G. and Koșun, E., 2003. The effects of Sewage on Benthic Community in Antalya Bay, Turkey. The Sixth International Conference on The Mediterranean Coastal Environment (MEDCOAST 03), 7-11 October Ravenna, Italy, 753-758.

[38] Turkish Statistical Institute (TSI). Belediye Atıksu I Istatistikleri Veri Tabanı. Data Set of Municipal Wastewater Statistics. Retrieved from the internet from http://tuikrapor.tuik.gov.tr/reports/ rwservlet?cevred $\quad \mathrm{b} 2=\&$ report=CEVAT13.RDF\&p_pkod=0\&p_yil1= 2006\&desformat=html\&p_dil=1\&ENVID=cevredb 2Env, 2006 (accessed on April 20, 2010).

[39] UNEP, Global environmental outlook 2000, Earthscan Publications,2000.

[40] Venturini, N., Muniz, P. and Rodíguez, M., 2004. Macrobenthic subtidal communities in relation to sediment pollution: the phylumlevel meta-analysis approach in a south-eastern coastal region of South America. Mar. Biol., 144,119-126.

[41] Yüksek, A., Okuș, E., Yılmaz, I.N., Aslan Yılmaz, A. and Taș, S, 2006. Changes in biodiversity of the extremely polluted Golden Horn Estuary following the improvements in water quality. Mar. Poll. Bul., 52, 1209-1218. 